\title{
"A sudden sickening sensation": South African prisoner-of-war experience on board the San Sebastian, December 1941
}

\section{Karen Horn*}

\begin{abstract}
During the Battle of Sidi Rezegh on 23 November 1941, a large number of volunteers from the Union Defence Force (UDF) was taken prisoner by Axis forces. Between 2 000 and 2500 of these men were transported to Italy on board the San Sebastian, an Italian cargo ship, which was torpedoed by HMS Porpoise on 12 December 1941. Following the attack, the San Sebastian ran aground on the Greek shore where Italian forces awaited the captives. The article places the San Sebastian incident in context by looking at the experience of battle and capture, as well as initial perceptions among prisoners-of-war (POWs) of their Italian captors. The behaviour of the Italian captain and many crew members led to a general sense of antagonism towards the Italians. The torpedoing of the ship and the increasing abhorrence towards their captors greatly influenced the way these POWs approached the remaining time in captivity, yet the individual responses from POWs prohibits simplified interpretations of the event. Relying on first-hand accounts provided by former POWs, memoirs and archival documents, this article presents an analysis of the different responses to the incident. Examples of conflict and cooperation between captives and captors are highlighted, as are cases of self-preservation, reprisal and aid to fellow POWs.
\end{abstract}

Key words: Prisoners-of-war; San Sebastian; Sidi Rezegh; South Africa; Union Defence Force; $5^{\text {th }}$ South African Infantry Brigade; World War Two.

\section{Opsomming}

Tydens die slag van Sidi Rezegh op 23 Desember 1941 is 'n groot aantal vrywilligers van die Unie-Verdedigingsmag gevange geneem deur magte van die Spilmoondhede. Tussen 2000 en 2500 van hierdie mans is na Italië vervoer op die San Sebastian, 'n Italiaanse vragskip, wat op 12 Desember 1941 deur the HMS Porpoise getorpedeer is. Na die aanval het die San Sebastian op die Griekse kus gestrand waar Italiaanse magte

* Dr Karen Horn is a senior lecturer in the Department of Curriculum Studies, Stellenbosch University where she teaches history education. She is the author of In Enemy Hands: South Africa's POWs in WWII, published by Jonathan Ball in 2015. Current projects include Italian POWs in the Union during WWII and lived experience of individuals in war.

How to cite this article: K. Horn, "'A sudden sickening sensation': South African prisoner-of-war experience on board the San Sebastian, December 1941", Historia, 63, 1, May 2018, pp 112-129. http://dx.doi.org/10.17159/2309-8392/2018/v63n1a6

Copyright: (C)The Author(s). Published under a Creative Commons Attribution Licence. 
die krygsgevangnes ingewag het. Die artikel plaas die San Sebastian-insident in konteks deur die ervaring van die veldslag en gevangeneming, asook die aanvanklike persepsies onder die krygsgevangenes oor hul Italiaanse gevangenemers, onder die loep te neem. Die optrede van die Italiaanse kaptein en baie bemanningslede het gelei tot ' $n$ algemene gevoel van antagonisme teenoor die Italianers. Die torpedoaanval en die toenemende afsku teenoor hul gevangenemers het die wyse waarop die krygsgevangenes die oorblywende tyd in aanhouding benader het, grootliks beïnvloed, tog verhoed individuele reaksies onder krygsgevangnes ' $n$ vereenvoudigde interpretasie van die gebeure. Deur staat te maak op persoonlike getuienisse van voormalige krygsgevangenes, memoirs en argivale bewysstukke, lewer die artikel 'n analise van die verskillende reaksies op die insident. Voorbeelde van konflik en samewerking tussen gevangenes en gevangenemers word beklemtoon, asook gevalle van selfbehoud, vergelding en hulp aan mede-krygsgevangenes.

Sleutelwoorde: Krygsgevangenes; San Sebastian; Sidi Rezegh; Suid-Afrika; UnieVerdedigingsmag; $5^{\text {de }}$ Suid-Afrikaanse Infanteriebrigade; Tweede Wêreldoorlog.

\section{Introduction}

On 12 May 1942, the deputy chief censor in Pretoria deleted a paragraph from a letter written by Sergeant Salomon Lutz, a prisoner-of-war who at the time of writing his letter was a patient in the Caserta Military Hospital in Naples. In the offending paragraph, Lutz described how the ship on which he was being transported from Benghazi to Italy had been hit by a torpedo, and that between 400 and 500 prisoners had lost their lives. But he added that he received "excellent treatment" from Italian hospital staff. ${ }^{1}$ Lutz was one of the estimated 2200 POWs who were captured by Axis forces during the Battle of Sidi Rezegh between 21 and 23 November 1941. Many of these POWs were from the $5^{\text {th }}$ South African Infantry Brigade which was active in Operation Crusader under the command of General Sir Claude Auchinleck, the Allied commander-in-chief in the Middle East. ${ }^{2}$ The ill-fated ship that Lutz mentioned was the San Sebastian, originally known as the Jason but also referred to as the Sebastian Venier or the Bastiano Veneri. She was torpedoed by the British submarine HMS Porpoise on 12 December 1941 and ran aground on Greek soil which at that time was occupied by Italian forces. ${ }^{3}$

Ironically, the only remaining evidence of Lutz's POW experience is the offending paragraph, and while records of censored documents such as this are available in archives, they do not offer a full picture of events. The fragmentary nature of such extracts are problematic when the goal of the historian is to gain an

1. Department of Defence Archive (hereafter DOD), Correspondence (hereafter CE) 4/15, Union of South Africa Censorship, Correspondence suspected to require special attention.

2. J.A. Brown, Retreat to Victory: A Springbok's Diary in North Africa: Gazala to El Alamein 1942 (Ashanti, Johannesburg, 1991), pp 32-33.

3. M. Leigh, Captives Courageous: South African Prisoners of War, World War II (Ashanti, Johannesburg, 1992), p 39. 
understanding of what happened. On the other hand, a number of scholars emphasise that while factual evidence remains important, the balance between the "life of the account", in other words, the context, and the hard facts, is equally crucial if historical accounts are to be seen as relevant and credible. ${ }^{4}$ In an effort to achieve a sense of historical accuracy, archival fragments such as Lutz's letter must therefore be supplemented by a wider collection of evidence. In this case written and oral testimonies from other South African POWs were consulted in an attempt to support a historical understanding of the event. It is to this evidence that this article looks in an attempt to narrate the details of the torpedo attack. Different versions from a number of individuals who experienced the attack illustrate the many diverse reactions to a single incident. As such, the narrative describes the lived experience of individuals and does not rely on broad generalisations.

As there are a number of first-hand accounts available about the attack on the San Sebastian, this article looks at individual experiences of POWs who were aboard the vessel when it was torpedoed in December 1941. More specifically, the article presents an analysis of the different ways the men reacted to the chaotic conditions in the minutes and hours after the attack. The focus then shifts to how the men reacted towards their captors and the extent to which the POWs viewed the Italians as the reason for their hardship, both in the aftermath of the attack and in subsequent captive experiences.

\section{Literature}

With regard to recent historiography on South African POW experience, very few published sources exist. Maxwell Leigh's Captives Courageous ${ }^{5}$ and Paul Schamberger's Interlude in Switzerland, ${ }^{6}$ provide insight into some aspects. While Schamberger's focus is on escape narrative, Leigh's work lacks critical analysis of POW experience, although it does provide a basic description of living conditions and day-to-day routine in Italian and German POW camps. More recently, In Enemy Hands: South Africa's POWs in WW II presents a narrative of the experience of the Union Defence Force volunteers who were POWs, including that of battle and capture, aspects of captivity in Italian and German- occupied territories, escape, repatriation and homecoming. ${ }^{7}$

In a wider sense, publications on the country's participation in World War Two have recently been described as "threadbare" and criticised as first succumbing to the pressures of the National Party government in the early years of apartheid, and later being used as a way to establish a sense of unity between Afrikaans and Englishspeaking South Africans. Shortly before the end of apartheid, a reverse strategy was

4. $\quad$ R. Samuel and P. Thompson, The Myths We Live by (Routledge, London, 1990), p 98.

5. Leigh, Captives Courageous.

6. P. Schamberger, Interlude in Switzerland: The Story of the South African RefugeeSoldiers in the Alps during the Second World War (Maus, Johannesburg, 2001).

7. K. Horn, In Enemy Hands South Africa's POWs in WWII (Jonathan Ball, Cape Town, 2015). 
employed, that of using the historiography of military participation as a way to illustrate to the rest of the world South Africa's significant contribution in the war against fascism. ${ }^{8}$

In the case of this article, a number of these primary sources are relevant to events on the San Sebastian and are used in conjunction with national and international secondary sources that refer to POWs during World War Two, or more specifically, to POW experience between 1939 and 1945. However, of the 2000 to 2 500 men who were on board the San Sebastian at the time of the attack, very few produced written accounts of their experience, and as such the available sources for this study is not representative. Nevertheless, it does present insight into the event and the way they responded to the attack.

In order to relay the experiences of those POWs on board the San Sebastian, research methods included the collection and analysis of personal accounts and written memoirs from those who were on board the ship. Archival searches were also carried out to gain some sense of the more contemporary accounts of the event. Interviews with former POWs were conducted during 2010, i.e. 69 years after the event. Written memoirs, mostly unpublished, began to appear from as early as the 1950s, but also as late at as the 1990s. Of those who were on the San Sebastian, both published and unpublished personal memoirs were available, for example accounts by Newman Robinson, ${ }^{9}$ Cyril Crompton ${ }^{10}$ and Herbert Rhodes ("Aussie") Hammond,11 while the memoirs of Vivian Rees-Bevan are included in Crwys-Williams's 1992 publication, A Country at War. ${ }^{12}$ Immediately following the war, a narrative report from a Mr Whittaker ${ }^{13}$ also provides a first-hand account of events on the San Sebastian, and of all the personal recollections, Whittaker's narrative is the most contemporaneous. Bernard Schwikkard's oral testimony and his memoirs also provide insight into the events of that night. ${ }^{14}$

8. D. Katz, "A Case of Arrested Development: The Historiography Relating to South Africa's Participation in the Second World War", Scientia Militaria, 40, 3 (2012), pp 280-285.

9. P. Ogilvie and N. Robinson, In the Bag (Macmillan, Johannesburg, 1975).

10. C. Crompton and P. Johnson, Luck's Favours: Two South African Second World War Memoirs (Echoing Green Press, Fish Hoek, 2010).

11. J. Chambers, For You the War is over: The Story of Herbert Rhodes (Aussie) Hammond (HAUM, Cape Town, 1967).

12. J. Crwys-Williams, A Country at War, 1939-1945: The Mood of a Nation (Ashanti, Rivonia, 1992).

13. DOD, Union War Histories (hereafter UWH), Narrative Reports (hereafter Narep), ME

3, Mr Whittaker, "Sidi Rezegh and Captivity afterwards (Greece and Italy)", related to Mrs G.R. de Wit by Mr Whittaker.

14. B.E. Schwikkard, My Life Briefly Told, Unpublished Memoirs, 1999; Interview, B.E. Schwikkard, Johannesburg, 17 March 2010. 


\section{Memory}

Bernard Schwikkard completed his memoirs in 1999. The author interviewed him in 2010, some eleven years later. A comparison between these two versions from the same man, provides an opportunity to analyse the effect of memory on his historical narrative. A similar method was used by Berntsen and Thomsen, who studied longterm memories among Danes who experienced the German occupation and liberation of Denmark during World War Two. ${ }^{15}$ By looking at all the accounts of events on the San Sebastian it becomes clear that memory, individual experience and the interpretation of the experiences lead to a number of different versions of the same event. However, at the same time, these diverse accounts are an aid to historical understanding.

Related in some measure to the matter of memory and narrative, is the almost complete loss of some historical data as a result of the influence of political ideologies both during the era of the historical event and when the written and oral narratives were recorded. ${ }^{16}$ One such example is the case of Private Fred Anthony Ernstzen, a Cape Corps man who was part of the $5^{\text {th }}$ Infantry Brigade. The information available from Ernstzen's grandson is very sketchy, but it is nevertheless clear that Ernstzen was on board the San Sebastian. Had it been possible to conduct an interview with Ernstzen, or if he had written an account of his experiences, it would have been possible to add another layer of diversity to the narrative. As it stands, this study relied largely on accounts by white English-speaking South Africans. A different voice among these would have been most useful to provide a more complete picture of events and how they were experienced. ${ }^{17}$

\section{Context}

In order to understand the reactions of POWs on board the San Sebastian, it is important to place the events preceding the journey across the Mediterranean into context. Starting with the chaotic Battle of Sidi Rezegh, the way the men were captured, the so-called thirst march, followed by the miserable conditions in the transit camps of Libya, the climax of the torpedo attack was a series of events that gradually worsened and influenced their perceptions of their captors, in some cases of each other and, in a wider sense, of the war itself.

The Battle of Sidi Rezegh, like many other battles in North Africa, was a confusion of troops and tanks moving back and forth in the desert. The aim of Operation Crusader was to relieve Australian forces at Tobruk and recapture

15. D. Berntsen and D.K. Thomsen, "Personal Memories for Remote Historical Events: Accuracy and Clarity of Flashbulb Memories Related to World War II", Journal of Experimental Psychology, 134, 2 (2005), p 243.

16. B. Nasson, South Africa at War 1939-1945 (Jacana, Johannesburg, 2012), p 22.

17. E-Mail correspondence, Zane Boltman, 22 February 2013. 
Cyrenaica - a goal that was only achieved in 1943.18 The conflict at Sidi Rezegh in 1941 came at a high cost. The entire $5^{\text {th }}$ South African Infantry Brigade was lost, with 224 killed, 379 wounded and about 3000 captured from the total force active at Sidi Rezegh. ${ }^{19}$ The $5^{\text {th }}$ Infantry Brigade, together with the $1^{\text {st }}$ and $2^{\text {nd }}$ Infantry Brigades, formed part of the $1^{\text {st }}$ South African Infantry Division which had acquired some battle experience en route to Cyrenaica, especially in Kenya, Abyssinia, Eritrea and Egypt. The successes at the Battle of El Wak and at Sollum, for instance, showed that the South Africans were adept at mobile bush warfare. ${ }^{20}$ However, it is also true that the Italian forces in East Africa were inadequately trained, badly equipped and disorderly, very unlike the formidable German forces that the South Africans were to face in the desert. ${ }^{21}$

The Battle of Sidi Rezegh is remembered by many South Africans as their first encounter with the German forces under the command of Lieutenant General Erwin Rommel. In his memoirs, Newman Robinson describes the German force at Sidi Rezegh almost as if they were robotic beings, wearing "grim set expression[s] as though [their] eyes were fixed on a vision of the Fuehrer beckoning [them] on to victory". ${ }^{22}$ This description underlines the stereotypical image held by many Allied soldiers of their German enemies. For Schwikkard, at another level, the methods employed at Sidi Rezegh resembled First World War tactics, involving the fixing of bayonets and being ready to charge an enemy that was "nowhere in sight". ${ }^{23}$ Cyril Crompton describes the conflict as moving "tremendously fast [with a] horrendous noise [and that] most devastating was the heavy artillery barrage that descended upon us". ${ }^{24}$ For Crompton, the brutal reality of war and its deadly consequences became piercingly clear when in the midst of the battle he encountered an old friend who had been separated from his regiment. As they shouted light-hearted, sarcastic comments about the battle at each other, his friend was hit and "fell dead into the sand". 25 Crompton was one of only four surviving members of the $3^{\text {rd }}$ Battery gun crew of the $1^{\text {st }}$ South African Anti-Aircraft Regiment. Following the battle, he re-joined the South African lines with great difficulty, only to see how they drove straight into German lines and "were made to lie face down ... and thus we were taken prisoner". ${ }^{26}$

18. G.A. Titterton, The Royal Navy and the Mediterranean, Volume 2: November 1940December 1941 (Routledge, London, 2002), p 138.

19. C. Somerville, Our War: How the British Commonwealth Fought the Second World War (Weidenfeld \& Nicolson, London, 1998), p 94.

20. G. Bentz, "From El Wak to Sidi Rezegh: The Union Defence Force's First Experience of Battle in East and North Africa, 1940-1941", Scientia Militaria, 40, 3 (2012).

21. J.A.I. Agar-Hamilton and L.C.F. Turner, Crisis in the Desert, May-July 1942 (Oxford University Press, Cape Town, 1952), pp 73-74.

22. Ogilvie and Robinson, In the Bag, p 12.

23. Schwikkard, My Life, $\mathrm{p} 24$.

24. Crompton and Johnson, Luck's Favours, p 32.

25. Crompton and Johnson, Luck's Favours, p 33.

26. Crompton and Johnson, Luck's Favours, p 37. 
In the days following the surrender, Rommel, now rewarded with the rank of field marshal, addressed the assembled POWs .27 Apparently he warned them that they "had a long way to go, and to be prepared for privation". ${ }^{28}$ In fact, they were handed over to the Italian authorities, which in turn initiated a complex relationship between captor and captive. Schwikkard remembers how Rommel,

the famous German Commander, drove up to us and said he was sorry to be handing us over to the Italians, but he needed all his soldiers to do the fighting. He indicated that, as soldiers, the Italians were a miserable lot. ${ }^{29}$

Statements such as these reinforce the long-held view of the Italians as an inferior ally as well as an inferior enemy, and in many subsequent POW memoirs, it is clear that the POWs regarded the Italians as ineffective and uncaring. In Rommel's case, it may have been to his benefit to encourage the spread of negative perceptions of the Italian forces to conceal to some extent his own lack of success in the field, or the way he regularly ignored military protocol by discussing war matters directly with Hitler. In a wider sense, the racist ideology held by many Germans at the time caused them to view their Italian allies as "racially inferior [which resulted in] endemic and pervasive" tension both on and off the battlefield. ${ }^{30}$

Whatever Rommel's personal reasons, his actions later that same month revealed something of his attitude towards the Italians. Deciding to retreat in December, he threatened the Italian commander-in-chief in Libya, Marshal Ettore Bastico, that if they could not reach an agreement, he was prepared to retreat through Cyrenaica leaving the Italians to fend for themselves. ${ }^{31}$

Many of those captured at Sidi Rezegh were marched to prison camps in what became known as the "thirst marches" among the captives. Newman Robinson was part of a group of about 2000 who marched for three days across the desert, during which time they had access to very little food and almost no water. On the first day of the march, Germans were in control, but at the day's end they were handed over to the Italians. Robinson thought that the Germans treated them with "cold efficiency", and that when the Italians took over, they "introduced a more human element of slapdash and muddle". ${ }^{32}$ Other POWs were not as kind and described the Italians in far more derogatory terms, evidence of negative attitudes towards Italians that

27. On 22 June 1942, the day after Rommel's victory at the Battle of Tobruk, Adolf Hitler promoted him to the rank of field marshal. See S.J. Zaloga, Kasserine Pass, Rommel's Last Victory (Osprey Publishing, Oxford, 2005), p 14.

28. DOD, Narep, ME 3, "Account of the Adventures of the Fellows Taken at Sidi Rezegh, Statement by Repatriated POW, 'Mr W'”.

29. Schwikkard, My Life, p 25.

30. J.J. Sadkovich, "Of Myths and Men: Rommel and the Italians in North Africa, 19401942", The International History Review, 13, 2 (1991), pp 284-286, 311.

31. E. Rommel and J. Pimlott (eds), Rommel in his Own Words (Greenhill Books, London, 1994), p 81.

32. Ogilvie and Robinson, In the Bag, p 21. 
worsened throughout their internment in North Africa and which would reach a climax during the journey across the Mediterranean towards Italy.

Most POWs spent about one or two weeks in North African transit camps before they were herded onto various vessels for the journey to Italy. During their short stay in the overcrowded and under-stocked transit camps, the majority of POWs formed very negative perceptions of their Italian captors, not least because of the use of Senussi guards and the use of excessive force and violence in misguided attempts to maintain order among the prisoners. In many cases prisoners were also required to hand over their personal possessions, especially their watches, to Italian sentries. Descriptions of incidents such as these are common in many POW memoirs and were not limited to the desert campaign or to the early years of the war. ${ }^{33}$

By comparing German tactical superiority and discipline with the seemingly disorganised Italian approach to the war in general, and with regard to the treatment of POWs, it is not surprising that the South Africans viewed the Germans in a favourable light. In some cases POWs even displayed a sense of admiration towards those German generals who were responsible for their captivity in the first place. ${ }^{34}$ The so-called thirst marches and the subsequent deprivation in the transit camps brought many POWs to a point of extreme demoralisation. For some, like Robinson, the move to the ship, and the expectation of improved conditions in Italy, was "refreshing". He did recall, however, upon seeing the San Sebastian lying in the bombed-out harbour, that he experienced the "slightly sick feeling which you get when you come unexpectedly upon a corpse". ${ }^{35}$ It is impossible to determine the extent to which hindsight contributed to this remark in his memoirs, which was written at least 33 years after the event. A number of interviews and memoirs also include misgivings about the Mediterranean crossing and many seemed to have been aware of the likelihood of falling victim to Allied torpedo attacks. Many of the men hoped to be rescued by the Allies before they set foot on the ships; unfortunately for them, the Allied forces were otherwise occupied at the time and did not make the hoped-for heroic appearance. Some POWs were lucky enough to have their rations of bread, biscuits and bully beef with them to sustain them on the journey. ${ }^{36}$ Others arrived at the docks with no provisions at all. ${ }^{37}$

\section{Under attack}

The number of POWs who boarded the San Sebastian differs in the available sources. Leigh states that 2200 men boarded the ill-fated ship, while Whittaker maintains that there were 2100 POW's aboard. ${ }^{38}$ Bernard Schwikkard estimated the number of

33. Chambers, For You the War is over, $\mathrm{p} 14$.

34. Ogilvie and Robinson, In the Bag, pp 25-26.

35. Ogilvie and Robinson, In the Bag, pp 28-29.

36. Crwys-Williams, $A$ Country at War, p 197.

37. Crompton and Johnson, Luck's Favours, p 41.

38. Leigh, Captives Courageous, p 39; DOD, UWH, Narep, ME 3, Whittaker, "Sidi Rezegh and Captivity afterwards". 
prisoners at 2 500, while Crwys-Williams puts the number at "over two thousand". ${ }^{39}$ Regardless of the head-count, the fact that they were leaving Africa and entering the cargo holds of the ships signified a new period of their captivity, one which for many POWs meant acceptance. For others the journey across the Mediterranean simply indicated a new phase of resisting their captors.

Crompton and Rees-Bevan both recalled in their memoirs that most of the POWs suffered from dysentery and that the facilities in the dark cargo holds were totally inadequate. ${ }^{40}$ In addition, the men were concerned about whether there was sufficient oxygen in the badly lit holds. On the morning of 9 December 1941 the men were allowed on deck in small groups and Aussie Hammond and Robinson were two of those who were able to make use of the opportunity for fresh air. ${ }^{41}$ The sight of the escorting Italian destroyers were of little comfort to them, especially as they were soon ordered back into the hold of the ship. They were acutely aware that there was only one ladder for the many men to escape should anything happen to the ship. ${ }^{42}$

The nervous tension most POWs experienced was realised at about 15:00 on 12 December when the ship was hit by a torpedo from the British submarine $H M S$ Porpoise. ${ }^{43}$ Crompton believed that many of those around him felt the same fear he experienced, and wrote about the "terror we felt of drowning". ${ }^{44} \mathrm{He}$ also compared his fear on the ship to that which he experienced during the Battle of Sidi Rezegh, once again stating his individual experience as the collective experience. ${ }^{45}$ Following the initial noise and chaos of the explosion, panic and desperation to escape from the hold of the ship subsided slightly as many realised that the ship was not sinking, or at least that it was sinking slowly. As such, some of the uninjured POWs attempted to help those who had been wounded. At the same time, others did what they could to escape, from what they believed was a sinking ship, and from their captors. ${ }^{46}$

The pandemonium following the attack on the ship and the Italians' panicky response served to dent the POW' opinion of their Italian captors. Both Whittaker and Schwikkard insisted that the ship's captain and most of the officers use the lifeboats to save themselves while many of the POWs were being sucked underwater by the ship's propellers as they tried to swim ashore.47 Both Mason and Gilbert corroborate the abandonment of the ship by the captain and crew and both record

39. Schwikkard, My Life, p 26; Crwys-Williams, A Country at War, p 197.

40. Crompton and Johnson, Luck's Favours, p 41; Crwys-Williams, A Country at War, p 197.

41. Chambers, For You the War is over, p 17; Ogilvie and Robinson, In the Bag, p. 29.

42. Ogilvie and Robinson, In the Bag, p 31; Crompton and Johnson, Luck's Favours, p 42; Crwys-Williams, A Country at War, p 197.

43. Leigh, Captives Courageous, p 39.

44. Crompton and Johnson, Luck's Favours, p 43, emphasis added.

45. Crompton and Johnson, Luck's Favours, p 43.

46. Chambers, For You the War is over, p 18.

47. DOD, UWH, Narep, ME 3, Whittaker, "Sidi Rezegh and Captivity afterwards"; Schwikkard, My Life, p 26. 
that a German naval engineer then took command. ${ }^{48}$ Yet the available historical record is unclear on the details.

In contrast to Whittaker and Schwikkard, Hammond's memoirs have the ship's crew under the command of a German captain, who "from the moment of disaster ... kept to his post, and did his best to inspire the crew to remain on board". ${ }^{49}$ In his account, Schwikkard maintains that a German captain took control of the situation when the Italian crew abandoned their posts, ordering the men to remain calm as he steered the ship towards the shore. ${ }^{50}$ Robinson, on the other hand, suggests that German engineers took control of the situation, while Whittaker, in his contemporary account, states that a South African, Sergeant Tillard of the $1^{\text {st }}$ South African Irish, took over once the captain and his officers abandoned the ship. ${ }^{51}$

These discrepancies on who controlled the ship are probably an indication of the immense confusion following the submarine attack. In all likelihood different individuals assumed control in different parts of the ship; some tried to restore order; others were determined to save themselves. Responses to the crisis at sea were anything but uniform. Once it was clear that the ship was not in danger of sinking, many POWs took matters into their own hands, reacting to the situation in a unique manner. While many responded to the events as if it was a life-threatening disaster, others experienced a rush of freedom and looked upon the incident as an adventure. This was the case with Aussie Hammond, whose descriptions do not convey any sense of horror or urgency as seen in other accounts. For instance, Robinson went on a "marauding expedition [for] blankets, coats and curtains for cover and towels and pillowslips for bandages, and got to work splinting broken limbs".52 In contrast, Hammond took time to deliver cognac to the medical orderlies and then "dashed back to join the feast in the galley". ${ }^{53}$ Similarly, Schwikkard remembers how a number of POWs took the opportunity to raid the ship's galley, where they found fresh bread which they washed down with alcohol from the cellar. ${ }^{54}$

For POWs, taking one's chance on the ship remaining afloat, or risking the sea, were tight decisions. Robinson recalls that those who jumped overboard tried to swim towards two escorting Italian destroyers, but that the Italian crews ignored their pleas for rescue. To make matters worse, these destroyers were also dropping depth charges in an effort to sink the British submarine and many POWs were killed by these

48. W.W. Mason, Prisoners of War: Official History Prisoners of War New Zealand in the Second World War 1939-45 (War History Branch, Department of Internal Affairs, Wellington, 1954), p 111; A. Gilbert, POW Allied Prisoners in Europe 1939-1945 (John Murray, London, 2006), p 49.

49. Chambers, For You the War is over, pp 16-18.

50. Interview: B.E. Schwikkard, Johannesburg, 17 March 2010.

51. Ogilvie and Robinson, In the Bag, p 31; DOD, UWH, Narep, ME 3, Whittaker, "Sidi Rezegh and Captivity afterwards".

52. Ogilvie and Robinson, In the Bag, p 33.

53. Chambers, For You the War is over, p 19.

54. Interview: B.E. Schwikkard, Johannesburg, 17 March 2010. 
explosions, while others died as waves smashed them against rocks. ${ }^{55}$ Crompton, however, viewed the depth charging as a lifesaver, because it deterred the British vessel from closing in again with another torpedo. ${ }^{56}$ All the while, the inability of the remaining Italians to take control of the deteriorating situation, "running all over the place, shouting and cursing", seemed to heighten the POWs animosity towards their lenemy, and a number of guards were thrown overboard by prisoners, "without any qualms at all". 57 Even in the midst of mounting chaos and panic, Italian guards appeared to find it difficult to break their routine of demanding an exchange of goods for services. In this way, Whittaker was forced to trade a pair of riding gloves for a lifebelt from one of the remaining guards who had apparently hidden away the safety equipment. ${ }^{58}$

In Whittaker's depiction, an unidentified South African POW swam to shore with a rope still attached to the ship, allowing many others to reach safety. ${ }^{59}$ Schwikkard, though, knew the man as Bernie Friedlander and describes how he:

... took a long rope from the deck, and bravely lowered himself into the sea. He was able to attach the rope onto some rocks below, and this enabled the rest of us to slide down the rope, wait for an incoming wave, drop in front of it, and get carried to the shore by the wave. I got ashore in this way ...60

The fact that Friedlander was recommended after the war for a George Medal with the support of a German officer, may also provide some verification of Schwikkard and Robinson's claims that a German officer or engineer took control when the Italian crew abandoned their ship. ${ }^{61}$ Crompton believed that German personnel were placed on the ship because the Germans did not trust the Italians, and this may also explain why a German officer took over when the Italians seemed to abandon all hope. ${ }^{62}$ On the other hand, Crompton's statement also supports the view, which is expressed in many memoirs, that UDF volunteers in general viewed German forces more favourably than they did Italian forces. That aside, it would seem that Friedlander was not the only POW who swam to shore in an effort to secure a system of ropes to save others. Crompton describes how being a strong swimmer as a result of his childhood river swimming experience in Natal, volunteered for the job. Securing his rope to a rock, it "became part of a network of other ropes down which the men could climb and swing ashore". 63

Regardless of the identity of the man who took command of the ship, he probably also saved lives because he steered the ship towards the shore, preventing it

55. Ogilvie and Robinson, In the Bag, p 31.

56. Crompton and Johnson, Luck's Favours, p 44.

57. Crwys-Williams, A Country at War, p 198.

58. DOD, UWH, Narep, ME 3, Whittaker, "Sidi Rezegh and Captivity afterwards".

59. DOD, UWH, Narep, ME 3, Whittaker, "Sidi Rezegh and Captivity Afterwards".

60. Schwikkard, My Life, p 27.

61. J.H. Mitchell, Transvaal Scottish Regimental Association: Regimental History, at http://www.jocks.co.za/history.htm (accessed 27 April 2011).

62. Crompton and Johnson, Luck's Favours, p 41.

63. Crompton and Johnson, Luck's Favours, p 45. 
from sinking in the deeper waters where it had been first hit by the torpedo. ${ }^{64}$ On the other hand, according to Crompton, many POWs who were in the water at the time were killed by the ship's churning propellers. ${ }^{65}$ Once ashore, the POWs were faced again by Italian soldiers who searched the drenched survivors and confiscated personal effects, a loss that embittered Schwikkard because his pocket watch, a gift from his mother, was taken. When those still on the ship saw what was happening to the survivors on shore, they decided to remain where they were, perhaps hoping somehow to avoid recapture and extend their brief period of freedom. Schwikkard's brother was one of those who remained behind, choosing the food and drink in the galley over the Italian looting on the beach. 66

When Robinson started thinking about leaving the ship it was dark and raining, so he decided to remain on board. He believed that he was in danger of drowning whether he stayed on board or tried to go ashore by the "precarious contraption of ropes". ${ }^{67}$ During the night he gave medical assistance to the wounded and in an effort to comfort them, invented a story that the Italians had radioed for a hospital ship and that it was on its way to collect them.68 In reality, according to Whittaker, a hospital ship did indeed come for the wounded. ${ }^{69}$ An Italian doctor boarded the ship the day after the attack and made arrangements for the injured men to be removed. Robinson himself remained on the ship until the last of the wounded were removed. ${ }^{70}$ Once all the patients were on their way, the rest of the POWs were forcibly removed from the ship by Italian soldiers. ${ }^{71}$

Robinson's experience of the attack and his attempts to aid the injured left him with new insights and opinions about the concept of the "enemy" and of the futility of war. Recalling the events at the time of writing his memoirs in 1975, he concluded that there was no distinction between friend and enemy, but he was bitter about

... the smug announcement which would report this and a thousand incidents like it: 'one of our submarines torpedoed an enemy merchantman off the coast of ... When last seen she appeared to be sinking by the bows'. If people could see what it was like they would never have applauded such news. If they knew what it was really like, I thought, they would say nothing on earth justified the torpedoing of ships at sea. ${ }^{72}$

\section{The aftermath of the attack}

The experience of relief for those injured appears to have softened the common negative view of the Italian adversary. Typically, Sgt Salomon Lutz wrote from the

64. Gilbert, POW, p 49.

65. Crompton and Johnson, Luck's Favours, p 45.

66. Interview: B.E. Schwikkard, Johannesburg, 17 March 2010.

67. Ogilvie and Robinson, In the Bag, p 35.

68. Ogilvie and Robinson, In the Bag, p 34.

69. DOD, UWH, Narep, ME 3, Whittaker, "Sidi Rezegh and Captivity afterwards".

70. $\quad$ Ogilvie and Robinson, In the Bag, p 36.

71. Schwikkard, My Life, p 27.

72. Ogilvie and Robinson, In the Bag, p 32. 
military hospital at Caserta in Naples in January 1942, that together with other wounded POWs, he was "picked up by a hospital boat and received excellent treatment". 73 The letters of other wounded POWs sent from the Caserta Military Hospital revealed that most POWs there were starting to view their captors in a more positive light, if only as a result of relatively good treatment received at that specific facility. In correspondence during February 1942, a South African POW noted that "treatment by Italians good, enough food", while another wrote that "although it is cold, [I have] a nice warm bed, Italians alright ...".74 Red Cross food parcels sent to the Caserta hospital certainly also helped to improve the patients' morale, as did the arrival of three British medical officers and a few British medical orderlies. Nevertheless, it seems that Caserta may have been an exception, for POWs treated at Bari endured "considerable neglect [and] shortage of food". ${ }^{75}$

On the other hand, for those not wounded and who reached the shore safely, it was be some time before their opinions of the Italian forces grew perceptively more positive. These prisoners now found themselves in Greece, in weather considerably colder than in North Africa, with most men still dressed in their desert uniforms, which for the most part comprised shorts and short-sleeved shirts. Some of those who had raided the galley for food also found blankets, which they brought ashore with them. The shared severity of common experiences, now worsened by cold, had an unexpected social consequence as it brought POWs together across the customary racial boundaries. Acute needs led to new forms of fraternisation, and Schwikkard's recollections include one of a coloured man from Cape Town:

[He]had a blanket, so we smooched up to him, and said look, come on man, let us share, and he was very kind, he agreed, but provided that he had the middle, and so four of us had a blanket ... ${ }^{76}$

Others had got rid of their clothes while still on the ship when they prepared to swim ashore, leaving them with only the bare minimum in the way of clothes. ${ }^{77}$ In ReesBevan's case, the ship's oil which covered him following his swim to shore is what he believed saved him from contracting pneumonia. ${ }^{78}$ From the shoreline, the POWs were taken to a barn near a submarine base, and from there they were marched to Pylos Castle where they were accommodated in the dungeons. The next destinations were Kalamatiria and then Aixia, where they were put into a wire enclosure, similar to the transit camps in North Africa. ${ }^{79}$

As the POWs were marched to their varying destinations, local Greeks lined

73. DOD, CE 4/15, Union of South Africa Censorship: Correspondence suspected to require special attention.

74. DOD, CE 4/15, Union of South Africa Censorship: Correspondence suspected to require special attention.

75. Mason, Prisoners of War, $\mathrm{p} 124$.

76. Interview: B.E. Schwikkard, Johannesburg, 17 March 2010.

77. Ogilvie and Robinson, In the Bag, p 36.

78. Crwys-Williams, A Country at War, p 199.

79. DOD, UWH, Narep, ME 3, Whittaker "Sidi Rezegh and Captivity afterwards". 
the streets attempting to hand out food, wine or cigarettes to the prisoners. ReesBevan encountered two Greek women who tried to give him currants and raisins, but this was stopped when the Italian guards fired at the women. ${ }^{80}$ In other instances, the Italians kept the locals away from the prisoners by using their bayonets and rifle butts. ${ }^{81}$ Once again, the behaviour of the Italians reinforced the POWs contempt for their captors. When Robinson saw Italian guards throwing stones at a Greek boy who was trying to hand cigarettes to the POWs, he lost all respect for what he sarcastically referred to as the "Second Roman Empire". ${ }^{82}$ Yet, in a simultaneous reflection he seemed also to lay some blame at the feet of the Germans for leaving the policing of occupied Greece to Italian forces. ${ }^{83}$

At Aixia the POWs were given small blankets, but conditions in the camp were so unhygienic that it soon became known among prisoners as "Dysentery Acre". 84 When they were moved to warehouses near the Patras harbour, a severe lice plague forced them all to spend their days "like monkeys catching fleas". ${ }^{85}$ A 45-gallon drum served as a toilet in each warehouse that housed approximately 300 men. The sheds were so crowded that the men had to take turns to fetch their food when it arrived, because the floor space was too small to occupy all of them simultaneously. ${ }^{86}$

While a number of POWs attempted to escape from the various makeshift camps in Greece, most were transported to Italy during February 1942. While the POWs were dispersed into different camps in southern Italy, the majority found themselves in Camp 66 near Capua; Camp 85 near Tuturano; or Camp 75 near Bari. ${ }^{87}$ Following the trauma of capture and their ordeal at sea, it was hardly surprising that POWs hoped conditions would improve once they reached the permanent camps where they expected to be housed in barracks instead of in tents. Moreover, they all looked forward to receiving Red Cross parcels; at that stage of their captivity they had not received any parcels at all. However, by the time POWs arrived at camps most were disheartened by what awaited them. The building of holding sites in Italy had not been completed and in many instances transit camps were hastily converted to permanent camps when more and more POWs arrived from North Africa. This was the case with Camp 85, which was listed as a transit camp in the third issue of the list of prison camps, but was described as a "permanent camp" by the Red Cross inspector when writing a report only a month later. ${ }^{88}$ Camp 85 later had thirteen

80. Crwys-Williams, A Country at War, p 199.

81. DOD, UWH, Narep ME 3, Whittaker, "Sidi Rezegh and Captivity afterwards"; Schwikkard, My Life, p 28.

82. $\quad$ Ogilvie and Robinson, In the Bag, p 38.

83. Ogilvie and Robinson, In the Bag, p 38.

84. Schwikkard, My Life, p 28.

85. Schwikkard, My Life, p 29.

86. Schwikkard, My Life, p 29.

87. Mason, Prisoners of War, $\mathrm{p} 112$.

88. DOD, Adjutant-General (hereafter AG), Prisoners of War (hereafter POW) 1504B/6, Vol. I, Camp locations by areas (Italy) including strengths. 
smaller work camps under its control according to a report compiled after a Red Cross inspection. 89

For those who remained in the large camps, POW life continued as a series of frustrations, ongoing battles against seemingly malicious Italian guards, boredom, fleas and the never-ending hunger pangs that were only relieved intermittently by Red Cross parcels. On the other hand, those rank and file men who volunteered their services to the surrounding work detachments enjoyed a relatively comfortable period until the armistice in August 1943. For the most part the work involved agricultural duties which not only allowed the prisoners greater freedom of movement, but also made food more easily obtainable. ${ }^{90}$

The lack of food and other commodities in the large camps quickly compelled POWs to enter into trading their Red Cross goods with locals and guards. On work detachments, POWs came into contact with local citizens and in both cases POWs began to realise that in general, the Italian peasants were living in terrible circumstances and furthermore, not all peasants supported the Fascist ideology. The growing awareness of the lack of food for Italian guards and civilians also produced some shift in attitude towards their captors. While still in North Africa, most POWs blamed guards for their terrible conditions and shortages, and open aggression and physical conflict between POWs and guards appears to have been fairly common. In Italy, however, many POWs felt pity towards the general Italian population. Equally, while on the surface relations between POWs and captors seemed to have improved somewhat in Italy, animosity and contempt were still the dominant emotions of POWs before the armistice. However, some South African POWs felt that the Italians were trying to adhere to the Geneva Convention despite common hardships. Article 11 of chapter 2 of the Geneva Convention states that "food ration of prisoners of war shall be equivalent in quantity and quality to that of the depot troops", ${ }^{91}$ however, the Italian authorities were unable to provide sufficient rations to their troops, which had the consequence that POWs remained at the bottom of the list when it came to handing out food. ${ }^{92}$

For those who experienced the torpedo attack on the San Sebastian, it appears that it was harder to change their perceptions. They remained largely negative and hostile and expressed these ideas in their memoirs or during interviews. For example, Schwikkard regarded trading food and cigarettes with the Italians as "doing their bit" in the war, especially because they were exchanging non-nutritious goods for

89. DOD, AG, POW, 1527/85, UDF, POW, Italian POW Camp No 85, Report by Rudolph I. Iselin on Camp No. 85, 8 March 1943.

90. Interview: D.W. Brokensha, Fish Hoek, 10 September 2010.

91. International Committee of the Red Cross (ICRC), International Humanitarian Law, Treaties and Documents, Convention relative to the treatment of Prisoners of War, Geneva, 27 July 1929. Available at http://www.icrc.org (accessed 30 May 2011).

92. National Archives of South Africa (hereafter NASA), Secretary of Foreign Affairs (BTS) 9/55/1, C, Vol. I, Correspondence from Secretary for External Affairs to High Commissioner, London, 1 March 1943. 
nutritious food. ${ }^{93}$ Moreover, he and others also soon realised that trading with civilians was more profitable and they made it a priority to be selected for work parties which would allow them to go outside the main camp and thereby afforded them more opportunity for exchanges. Robinson reflects that after some time in Italy, relationships between the POWs and the Italians were "not affectionate [but] seriocomic (sic) rather than hostile". ${ }^{94}$ He believed that this was because of less frequent contact between POWs and Italian guards, although he reminds his readers that immediately after capture they "hated and despised the Italian troops for profiteering on water when [POWs] were dying of thirst in the desert, and for their indifference to the men drowning in, and off, the San Sebastian". ${ }^{95}$

Perhaps the most striking incident of veiled revenge on his Italian captors was Aussie Hammond being able to inform the Italian prison guards at his camp that Italy had capitulated. ${ }^{96}$ He was able to do this due to a complex and elaborate system of hidden radios and secret exchanges of newspapers for cigarettes between POWs and guards. Hammond remembers: "our guards laughed when we gave them the news first, but they accepted the official confirmation shortly afterwards with their usual shrug of the shoulders". ${ }^{97}$ These statements and the experiences of some of the San Sebastian POWs are in striking contrast to other POWs who enjoyed a less eventful crossing to Italy, with some men even describing the period in Italy as "among the happier memories of my captivity" 98 and in describing their farm work, as "a Godsend". 99

\section{Concluding perspectives}

The experience of battle and capture at Sidi Rezegh, the subsequent deprivation in the so-called hell camps of North Africa, the shock of the torpedo attack and witnessing men drowning, followed by further ordeals in Greece and the final disappointment in Italy when the POWs realised that their circumstances would not improve significantly, influenced the way many of these POWs viewed and approached the rest of their captivity. It also dictated, to an extent, the information they chose to share in memoirs or during interviews. These men came to rely less on the Italian captors and more on their own ingenuity for their wellbeing. This state of affairs brought about a situation which created a very specific type of relationship between POWs and captors; that of hostility, veiled at times with humour and at other times with open conflict.

93. Interview: B.E. Schwikkard, Johannesburg, 17 March 2010.

94. Ogilvie and Robinson, In the Bag, p 66.

95. Ogilvie and Robinson, In the Bag, p 66.

96. Chambers, For You the War is over, $\mathrm{p} 63$.

97. Chambers, For You the War is over, $\mathrm{p} 63$.

98. D.W. Brokensha, Brokie's Way: An Anthropologist's Story (Amani Press, Fish Hoek, 2007), p 89.

99. Interview: W. Hindshaw, Johannesburg, 19 March 2010. 
On the other hand, the relationships between captor and captive were not unique to the men who boarded the San Sebastian, because many POWs displayed similar behaviour in both Italy and Germany. What may have been unique to the San Sebastian experience was how difficult it was for these POWs to change their initial negative perceptions towards the Italians. The experiences of POWs on board the stricken vessel, and more specifically their encounters with Italian guards and the command of the ship, determined largely how the POWs were able to adjust their perceptions of their captors and how they were able to adjust to their captivity in Italy. So, while the POWs witnessed distressing events during the attack, and regarded the behaviour of the Italians as unacceptable in the hours afterwards, the reaction among captives varied widely. In short, the way POWs responded to the torpedoing of the San Sebastian, determined to a large extent their attitude towards captivity in the years following the event.

Almost a year later, in August 1942, another ship, the Nino Bixio, also packed with POWs, was hit by a torpedo from the British submarine HMS Turbulent while crossing the Mediterranean. In this disaster, 432 men lost their lives in the blast, after which the ship was steered to Navarino on the Greek coast. ${ }^{100}$ As a result of incidents such as these that resulted in the deaths of many Allied POWs, the belligerents attempted to reach an agreement on displaying distinguishing signs on ships which were carrying prisoners. They also attempted to set guidelines for safety measures on board the ships, including that of sufficient lifeboats. Unfortunately, however, the Allied and Axis authorities did not conclude their negotiations successfully. ${ }^{101}$

\section{REFERENCES}

Agar-Hamilton, J.A.I. and Turner, L.C.F., Crisis in the Desert May-July 1942 (Oxford University Press, Cape Town, 1952).

Bentz, G., "From El Wak to Sidi Rezegh: The Union Defence Force's First Experience of Battle in East and North Africa, 1940-1941", Scientia Militaria, 40, 3 (2012).

Berntsen, D. and Thomsen, D.K., "Personal Memories for Remote Historical Events: Accuracy and Clarity of Flashbulb Memories Related to World War II", Journal of Experimental Psychology, 134, 2 (2005).

Brokensha, D.W., Brokie's Way: An Anthropologist's Story (Amani Press, Fish Hoek, 2007).

Brown, J.A., Retreat to Victory, a Springbok's Diary in North Africa: Gazala to El Alamein 1942 (Ashanti, Johannesburg, 1991).

Chambers, J., For You the War is over: The Story of Herbert Rhodes (Aussie) Hammond (HAUM, Cape Town, 1967).

Crompton, C and Johnson, P., Luck's Favours. Two South African Second World War Memoirs (Echoing Green Press, Fish Hoek, 2010).

Crwys-Williams, J., A Country at War 1939-1945: The Mood of a Nation (Ashanti, Rivonia, 1992).

100. Gilbert, POW, p 51.

101. Mason, Prisoners of War, p 147. 
Gilbert, A., POW Allied Prisoners in Europe, 1939-1945 (John Murray, London, 2006).

Horn, K., In Enemy Hands: South Africa's POWs in WWII (Jonathan Ball, Cape Town, 2015).

Katz, D., "A Case of Arrested Development: The Historiography Relating to South Africa's Participation in the Second World War", Scientia Militaria, 40, 3 (2012).

Leigh, M., Captives Courageous: South African Prisoners of War World War II (Ashanti, Johannesburg, 1992).

Mason, W.W., Prisoners of War Official History: Prisoners of War New Zealand in the Second World War 1939-45 (War History Branch, Department of Internal Affairs, Wellington, 1954).

Mitchell, J.H., Transvaal Scottish Regimental Association: Regimental History, at http://www.jocks.co.za/history.htm (accessed 27 April 2011).

Nasson, B., South Africa at War 1939-1945 (Jacana, Johannesburg, 2012).

Ogilvie, P. and Robinson, N., In the Bag (Macmillan, Johannesburg, 1975).

Rommel, E. and Pimlott, J., (eds) Rommel in his Own Words (Greenhill Books, London, 1994).

Sadkovich, J.J., "Of Myths and Men: Rommel and the Italians in North Africa, 19401942", The International History Review, 13, 2 (1991).

Samuel, R. and Thompson, P., The Myths We Live by (Routledge, London, 1990).

Schamberger, P., Interlude in Switzerland: The Story of the South African RefugeeSoldiers in the Alps during the Second World War (Maus, Johannesburg, 2001).

Schwikkard, B.E., My Life Briefly Told, Unpublished Memoirs, 1999.

Somerville, C., Our War: How the British Commonwealth Fought the Second World War (Weidenfeld \& Nicolson, London, 1998).

Titterton, G.A., The Royal Navy and the Mediterranean, Volume 2, November 1940December 1941 (Routledge, London, 2002).

Zaloga, S.J., Kasserine Pass Rommel's last victory (Osprey Publishing, Oxford, 2005). 